\title{
SETTINGS PARAMETERS FOR AERIAL PESTICIDES APPLICATION USING GYROPLANE
}

\author{
Zbigniew CZACZYK ${ }^{1}$, Bradley K. FRITZ ${ }^{2}$, W. Clint HOFFMANN ${ }^{2}$, \\ Sławomir MAJEWSKI ${ }^{3}$ \\ ${ }^{1}$ Guest researcher at USDA-ARS, Aerial Application Technology Research Unit, College Station, USA \\ ${ }^{2}$ USDA-ARS, Aerial Application Technology Research Unit, College Station, TX 77845, USA \\ ${ }^{3}$ Regional Directorate of the State Forests in Piła, Forest Protection Dept., POLAND \\ E-mail of corresponding author: zbigcza@ gmail.com
}

Keywords: aerial spraying, spraying characteristics, drift control, forest protection, gyroplane

\begin{abstract}
The operational effectivity of pesticide application on small areas of forests $(<5$ ha) could be improved e.g. by using gyroplanes. The gyroplane is powered by standard automotive fuel, and can be operated without airport infrastructure. For safe and efficient use of such technology an elaboration of working settings is needed. Three most widely used insecticides for protection of Polish forests were tested. In the conducted study new applications parameters (forward speed, flow rate) adapted to gyroplane were used. The rotating atomisers AU 7000 were adapted to gyroplane, to receive the application of insecticides, similar to quality received by aircraft. Additionally, the same dose rates of tank mixes were tested, but for application speed optimized for gyroplane $(100 \mathrm{~km} / \mathrm{h})$.
\end{abstract}

\section{INTRODUCTION}

In Poland, each year hundred thousands of hectares of forest need insecticide application. The areas for spraying have very different sizes and mostly irregular shapes. As reported Majewski (2015) it influences the operational efficiency of aerial application which depends also on meteorological situation and phenology of pests. Because in the last decades, as reported Bungescu et al. 2011), Giles \& Billing (2014), Xiongkui He et al. (2014), Bzowska-Bakalarz et al. (2015), new options of aircraft in crop protection were adapted: ultralight trike, gyroplane (both operated by pilot), and unmanned aerial vehicles (UAV), or unmanned aerial systems (UAS): drones and helicopters (operator working from the ground).

These ultralight aerial vehicles are easier to control, are powered by standard automotive fuel (not aviation fuel), and can work without accredited airport (infrastructure). Any airport and airstrip should have permission from the applicable civil aviation authority.

When making any agrochemical spray application, the primary concerns are ensuring maximum biological efficacy while minimizing any off-target movement and adverse environmental impact or other non-target biological harm. One of the principal factors to consider when setting up any sprayer prior to an application is droplet size, which has long been recognized by many researchers (Teske \& Barry 1993, Hewitt 1997, Miller \& Butler Ellis 2000, USDA 2006, Czaczyk 2014, Matthews et al. 2014) as one of the primary parameters influencing overall spray deposition, efficacy, and drift.

For aerial application of the most common insecticides in Poland, an ultra-low volume (ULV) technology is used. It allows spraying with oil based tank mixes - not sensitive to fast evaporation during application. Woziński (1995) and Rowiński (2009) reported on how to operate with applications by planes and helicopters under Polish conditions. Also other sources are available - e.g. USDA (2006), Matthews et al. (2014) with descriptions of spraying setting selection. Majewski (2016) reported significant progress when using e.g. gyroplane on small areas ( $<5 \mathrm{ha}$ ) of forests. The cruise speed range for gyroplanes is between 50 and $170 \mathrm{~km} / \mathrm{h}$. The range of working speed for AU 7000 rotating atomiser 
determined by Micron Group (2016) result in between 64 and $160 \mathrm{~km} / \mathrm{h}$. The liquid output variable: 0 - $10 \mathrm{l} / \mathrm{min}$, and spraying characteristics variable described by volume median diameter (VMD) is between $\varnothing 60-750 \mu \mathrm{m}$.

For an optimisation of economic efficiency, a special algorithm was elaborated by Majewski (2016). For the purpose of national forests protection, three original tank mixes were used in the conducted study, similar to those used with typical aircraft.

The objective of this study was to develop and evaluate application settings for gyroplane associated with application by typical aircraft.

\section{MATERIAL AND METHODS}

\section{Liquids tested in the study}

The key and mixing rates for the products used in conducted study (tab. 1.):

Product 1: Water Only (control);

Product 2: Bt Solution $200 \mathrm{ml} / 4$ 1;

Product 3: Dimilin 480 SC $100 \mathrm{ml}+1.71$ of Ikar 95 EC in a total solution of 4 gal;

Product 4: Tristar $30 \mathrm{SG}$ (acetamiprid as the active ingredient) at $80 \mathrm{ml}+21$ of Ikar

$95 \mathrm{EC}$ in total solution of $4 \mathrm{gal}$.

\section{Application Parameters}

The application speed for conducted study was $100 \mathrm{~km} / \mathrm{h}$;

The working pressure of tested tank mixes was $276 \mathrm{kPa}$ (40 psi).

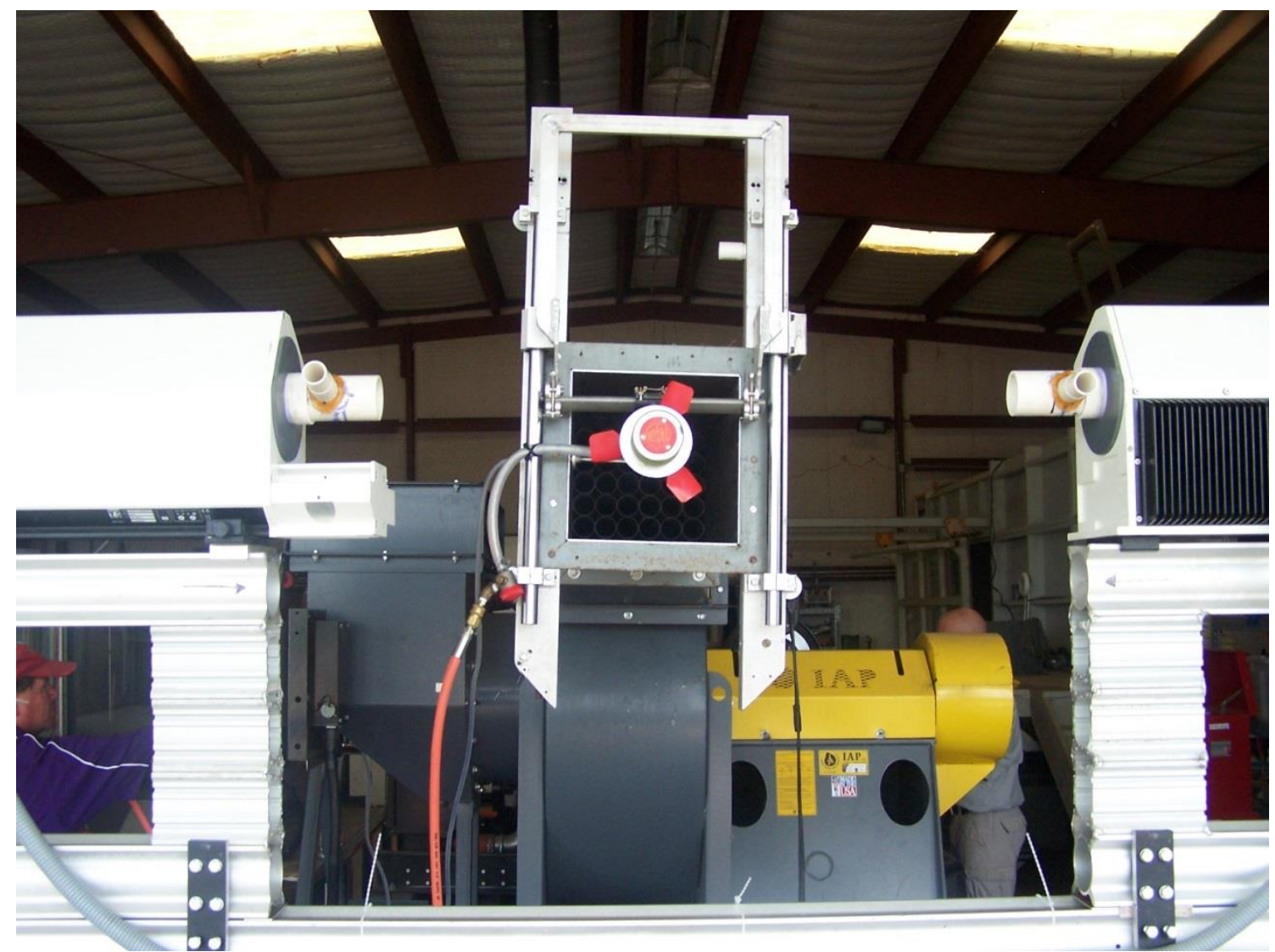

Figure 1. View of rotating atomiser in testing position. (photographed by Zb. Czaczyk). 


\section{Droplet Size Measurements}

Droplet sizing measurements were conducted at the United States Department of Agriculture (USDA), Agricultural Research Service (ARS) Aerial Application Technology Research Unit's (AATRU) laboratory located in College Station, Texas. Testing Procedure All tests were conducted at the high-speed wind tunnel (HSWT), at USDA-ARS in College Station, TX. The USDA-ARS HSWT consists of a high speed centrifugal blower powered by a $48.5 \mathrm{~kW}$ ( $65 \mathrm{hp}$ ) gasoline engine. The blower speed is controlled by adjusting the engine's throttle. The high-speed air generated by the blower, exhausts through a $50.8 \times 50.8 \mathrm{~cm}$ outlet. The air velocity is measured directly at the outlet, using a Pitot tube attached to an airspeed indicator. A $30 \mathrm{~cm}$ section of aircraft boom was mounted directly at the tunnel's outlet.

Spray solutions were fed from 191 stainless steel pressure tanks which were pressurized using an air compressor. A pressure regulator was used to change pressure, which was measured using an electronic pressure gauge (PX409-100GUSB, Omega Engineering, Stamford CT) positioned within $20 \mathrm{~cm}$ of the atomiser outlet. A Sympatec HELOS Vario ${ }^{\circledR}$ laser diffraction system (operated with the manufacturer denoted R5 lens, dynamic size range of $\varnothing 0.5-875 \mu \mathrm{m}$ across 32 bins) was positioned downstream of the nozzle such that the area of measurement was $45 \mathrm{~cm}$ from the exit of the tested atomiser. Evaluation of each treatment (Table 1) consisted of a series of replicated measurements. Sufficient replications were made to ensure that the standard deviations of $\mathrm{D}_{\mathrm{v} 0.1}, \mathrm{D}_{\mathrm{v} 0.5}$, and $\mathrm{D}_{\mathrm{v} 0.9}$ according ANSI/ASAE (2009) were within $\pm 5 \%$ of the means as well as the Relative Span (RS). Additionally, the percentage volumes of characteristic droplet size fractions of the spray $\mathrm{V}_{<\mathrm{x}}\left(\%_{\mathrm{vol}}\right)$ contained in droplets less than (x size): $\varnothing 50,80,100,141,150$, 200 and $730 \mu \mathrm{m}$ was also recorded.

\section{RESULTS}

Table 1. Spraying characteristics for four tested tank mixes at $276 \mathrm{kPa}$ liquid pressure, simulated flight speed $100 \mathrm{~km} / \mathrm{h}$, for rotating atomiser AU 7000. (source - own study)

\begin{tabular}{|c|c|c|c|c|c|c|c|c|c|c|c|c|}
\hline Product & Rep & $\mathrm{D}_{\mathrm{v} 10}$ & $\mathrm{D}_{\mathrm{v} 50}$ & $\mathrm{D}_{\mathrm{v} 90}$ & $\mathrm{RS}$ & $\mathrm{V}_{<50}$ & $\mathrm{~V}_{<80}$ & $\mathrm{~V}_{<100}$ & $\mathrm{~V}_{<141}$ & $\mathrm{~V}_{<150}$ & $\mathrm{~V}_{<200}$ & $\mathrm{~V}_{<730}$ \\
\hline 1 & 1 & 17.11 & 53.44 & 173.72 & 2.93 & 47.37 & 64.09 & 71.67 & 83.47 & 85.72 & 93.31 & 100 \\
1 & 2 & 17.10 & 53.47 & 176.35 & 2.98 & 47.35 & 64.12 & 71.66 & 83.20 & 85.39 & 92.78 & 100 \\
1 & 3 & 17.19 & 54.04 & 177.16 & 2.96 & 47.00 & 63.74 & 71.32 & 82.96 & 85.17 & 92.69 & 100 \\
\hline 2 & 1 & 16.79 & 52.17 & 166.99 & 2.88 & 48.18 & 66.42 & 74.47 & 85.45 & 87.42 & 93.82 & 100 \\
2 & 2 & 17.24 & 53.49 & 169.26 & 2.84 & 47.21 & 65.56 & 73.75 & 84.98 & 86.99 & 93.57 & 100 \\
2 & 3 & 17.19 & 53.61 & 169.02 & 2.83 & 47.14 & 65.49 & 73.69 & 84.98 & 87.01 & 93.64 & 100 \\
\hline 3 & 1 & 17.04 & 49.42 & 144.10 & 2.57 & 50.58 & 72.27 & 80.63 & 89.53 & 90.91 & 94.84 & 100 \\
3 & 2 & 17.04 & 49.49 & 143.66 & 2.56 & 50.51 & 72.24 & 80.62 & 89.59 & 90.98 & 94.92 & 100 \\
3 & 3 & 17.00 & 49.30 & 144.61 & 2.59 & 50.70 & 72.30 & 80.59 & 89.45 & 90.82 & 94.73 & 100 \\
\hline 4 & 1 & 16.91 & 48.93 & 142.05 & 2.56 & 51.08 & 72.85 & 81.11 & 89.84 & 91.19 & 94.93 & 100 \\
4 & 2 & 17.17 & 49.28 & 143.74 & 2.57 & 50.72 & 72.46 & 80.77 & 89.59 & 90.95 & 94.79 & 100 \\
4 & 3 & 17.04 & 48.62 & 142.94 & 2.59 & 51.40 & 72.99 & 81.12 & 89.71 & 91.04 & 94.77 & 100 \\
\hline
\end{tabular}




\section{CONCLUSIONS}

The technologies in sustainable agriculture require adaptation of new available techniques and settings for the employed equipment. As reported Majewski (2016) on the pest control in smaller areas (especially smaller than $5 \mathrm{ha}$ ) of forests, a typical aerial equipment (plane, helicopter) operation is very ineffective. It was possible to compare, after pioneering use of gyroplane for pest control in the Piła region. Documented operational profits allow realisation of economical and environmentally friendly pesticide application. Selected rotating atomiser AU 7000 and settings deliver spraying characteristics presented in table 1 . The received values allow looking for optimisation of atomisation quality for the applied insecticides. For further development of optimised and environmentally friendly application techniques, it is necessary to evaluate spraying characteristics of working liquids. To evaluate and confirm an operational settings of advanced application technique, the next research is needed. Using gyroplane for pest control, also for arable crops, the $\mathrm{CO}_{2}$ emission could be reduced.

\section{REFERENCES}

ANSI/ASAE S572.1. (2009). Spray Nozzle Classification by Drop Spectra. The American Society of Agricultural and Biological Engineers (ASABE) Standards, St. Joseph, MI, USA, 4 pp.

Bungescu, S. T., Pape, J., Stahl,i W., Vladut, V., Biris, S. \& Atanasov, A. (2011). Research on the use of gyrocopter for granulated crop protection products administration. Balk. Agric. Eng. Rev., 16, 9-14.

Bzowska-Bakalarz, M., Trendak, A., Marszałek, D., Pniak, M., Bagar, M. \& Czarnigowski, J. (2015). Aerial method of plant protection with the use of an autogyro for sustainable agriculture. Agric. Agric. Sc. Procedia, 7, 54-58.

Czaczyk, Z. (2014). Drop-size classification according to requirements of pesticides labels. Prog. Plant Prot. 54 (1), 111-120.

Giles, D. K., \& Billing, R. (2014). Unmanned aerial platforms for spraying: Deployment and performance. Asp. Appl. Biol. 122, Int. Adv. Pest. Appl., 63-69.

Hewitt, A. J. (1997). Droplet Size and Agricultural Spraying, Part 1: Atomization, Spray Transport, Deposition, Drift, and Droplet Size Measurement Techniques. Atomization Sprays 7 (3), 235-244.

Hoffmann, W. C., Fritz, B. K., Farooq, M., Czaczyk, Z., Walker, T. W., Hornsby, J. \& Bonds, J. A. S. (2013). Evaluation of aerial spray technologies for adult mosquito control applications. J. Plant Prot. Res. 53 (3), 222-229.

Majewski, S. (2015). Factors affecting the efficiency and costs of airborne spraying in Regional Directorate of the State Forests in Piła in 2013. Sylwan, 159 (4), 289-299.

Majewski, S. (2016). Efficiency of treatments reducing population of folivorous insects realized by various types of aircrafts. PhD thesis, Forest Res. Institute, Sękocin Stary, 154 pp.

Matthews, G. A., Bateman, R. P. \& Miller P. C. H. (2014). Pesticide Application Methods, $4^{\text {th }}$ Edition, ISBN: 978-1-118-35130-7, Wiley-Backwell, Oxford, 536 pp.

Micron Group (2016). Micron Air AU 7000 Atomiser, Operator's Handbook and Parts Catalogue. 43 pp. http://www.microngroup.com/micronair_atomiser_range_for_helicopters, (accessed 15.05.2016)

Miller, P.C.H., \& Butler Ellis, M. C. (2000). Effects of Formulation on Spray Nozzle Performance for Applications from Ground-Based Boom Sprayers. Crop Prot. 19 (8-10), 609-615.

Rowiński, R. S. (2009). Warunki wykonywania zabiegów agrolotniczych. Zabiegi agrolotnicze w ochronie lasu. CILP, Warszawa, 43-48.

Teske, M. E., \& Barry, J. W. (1993). Parametric Sensitivity in Aerial Application. Trans. ASAE 36 (1), 27-33. 
USDA (2006). Aerial Application Manual. accessed 12 August 2017, INTERIM Edn. 10/2006, 402 pp. https://www.aphis.usda.gov/import_export/plants/manuals/domestic/downloads/aam.pdf

Woziński, Z. (1995). Znowelizowana instrukcja technologiczna zwalczania szkodliwych owadów liściożernych w lasach. Lasy Państwowe, Instytut Badawczy Leśnictwa. 48 pp.

Xiongkui, He, Yajia, Liu Jianli Song, Aijun Zeng \& Jing Zhang (2014). Small unmanned aircraft application techniques and their impacts for chemical control in Asian rice fields. Asp. Appl. Biol. 122, Int. Adv. Pest. Appl., 33-45. 